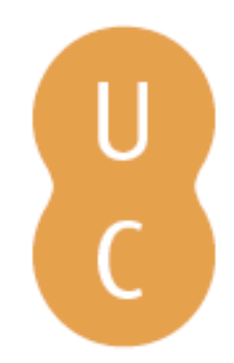

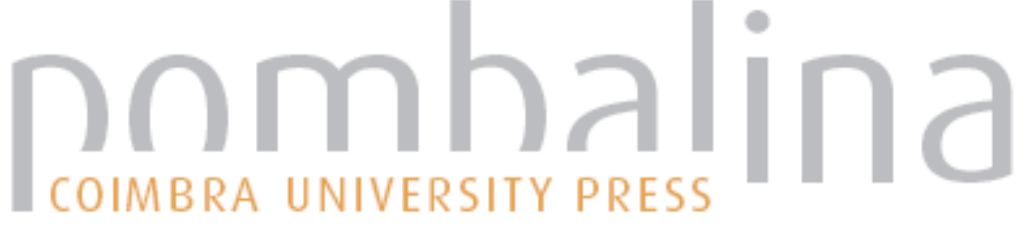

\section{Caminhos narrativos: um personagem: o brasileiro}

Autor(es): $\quad$ Mota, Célia Maria Ladeira; Vieira, Leylianne Alves

Publicado por: Imprensa da Universidade de Coimbra

URL

persistente:

URI:http://hdl.handle.net/10316.2/41352

DOI:

DOI:https://doi.org/10.14195/978-989-26-1324-6_11

Accessed : $\quad$ 26-Apr-2023 02:07:34

A navegação consulta e descarregamento dos títulos inseridos nas Bibliotecas Digitais UC Digitalis, UC Pombalina e UC Impactum, pressupõem a aceitação plena e sem reservas dos Termos e Condições de Uso destas Bibliotecas Digitais, disponíveis em https://digitalis.uc.pt/pt-pt/termos.

Conforme exposto nos referidos Termos e Condições de Uso, o descarregamento de títulos de acesso restrito requer uma licença válida de autorização devendo o utilizador aceder ao(s) documento(s) a partir de um endereço de IP da instituição detentora da supramencionada licença.

Ao utilizador é apenas permitido o descarregamento para uso pessoal, pelo que o emprego do(s) título(s) descarregado(s) para outro fim, designadamente comercial, carece de autorização do respetivo autor ou editor da obra.

Na medida em que todas as obras da UC Digitalis se encontram protegidas pelo Código do Direito de Autor e Direitos Conexos e demais legislação aplicável, toda a cópia, parcial ou total, deste documento, nos casos em que é legalmente admitida, deverá conter ou fazer-se acompanhar por este aviso.

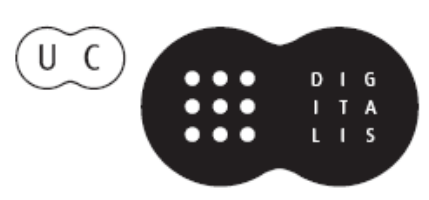





\title{
CAMINHOS NARRATIVOS: UM PERSONAGEM: O BRASILEIRO
}

\author{
Célia Maria Ladeira Mota \\ Programa de Pós-graduação \\ Faculdade de Comunicação, UnB \\ Leylianne Alves Vieira \\ Programa de Pós-graduação \\ Faculdade de Comunicação, UnB
}

No livro Morfologia do Conto Maravilhoso, o autor, Vladimir Propp (1970), nos dá uma definição simples e clara sobre o personagem e sua função: é o ser que realiza uma ação que é a base da intriga de um conto. Personagem é, assim, o ser humano em movimento, seja na vida pessoal, individual, seja nas narrativas ficcionais ou nos relatos jornalísticos. Sua participação num relato viabiliza detalhes de descrição física ou social e determina a interação com grupos sociais. É a partir da vivência do personagem que os relatos ganham vida e se tornam fonte para os narradores. O ponto de partida para a análise de personagens é, portanto, o mundo da vida, uma expressão que define a experiência vivida.

Neste artigo, analisamos a caracterização de um personagem como é concebida em dois gêneros narrativos: o ficcional e o jornalístico. Vamos observar como o brasileiro é representado em Macunaíma, 
na obra de Mário de Andrade, e na reportagem da revista Realidade "O canavial esmaga o homem", que conta a saga de Gregório, um trabalhador de engenho. $\mathrm{O}$ foco é perceber as subjetividades dos relatos e os contrastes entre a fantasia e a realidade e compreender os significados construídos. São representações da identidade do brasileiro que têm sua origem em duas matrizes culturais que herdamos dos portugueses: a aventura e o trabalho.

O caminho teórico é o da Análise Crítica da Narrativa, como proposta por Motta, para quem "esta análise é um caminho rumo ao significado e o significado é uma relação: não há significado sem algum tipo de troca (Motta, 2013: 121). Investigando as jornadas dos dois personagens e os acontecimentos nos quais se envolvem, de acordo com o ciclo do herói proposto por Campbell (2007), a análise estuda os significados que emergem de práticas culturais que têm raízes históricas e que até hoje contribuem para uma certa ambiguidade na concepção do personagem brasileiro.

\title{
O personagem: um ator?
}

\begin{abstract}
A vida nada mais é do que uma sombra, um pobre ator que se pavoneia no palco, e então não é mais ouvido. É uma estória contada por um idiota, cheia de som e fúria, que significa nada. (Shakespeare, em Macbeth).
\end{abstract}

Ao se basear em personagens fictícios que reproduzem as relações de poder e as intrigas de cortes europeias do século XVII, Shakespeare coloca considerações filosóficas nas falas dos atores. Seus textos se dividem entre relatos de acontecimentos trágicos e falas, monólogos e diálogos, que buscam oferecer um significado para os fatos. Para Shakespeare, o drama, cheio de som e fúria, terminava quase sempre com a morte. Suas concepções lembram Platão que, 
muitos anos antes, afirmara ser a obra dramática uma arte ilusória que refletia o mundo de aparências à sua volta. O poeta, dizia Platão, com sua arte ilusória diz o falso como verdade. Para Platão, por não imitar a ideia, mas a aparência sensível, a criação mimética opera por ilusões e se torna degradante. O termo grego mímesis tem sido geralmente traduzido por 'imitar', e, por isso, nos termos de Platão, o drama seria uma imitação pobre da realidade. O conceito dividiu dois sistemas filosóficos gregos, o platônico e o aristotélico: seria a mímesis uma simples cópia da realidade ou uma reapresentação deste mundo exterior? Cópia ou imitação criativa?

Ricoeur (1994) nega a imitação e afirma que a narrativa é uma releitura da vida, uma cópia criativa em torno de novos significados. Seguindo Aristóteles em sua Arte Poética, o autor francês considera que o objeto da mímesis é a ação humana e, assim, incorpora diferentes interpretações do real. Este ponto de vista adota a ideia de verossimilhança entre seres ficcionais e o ser humano real, lembrando Aristóteles que afirmava ser o objeto da poiesis imitar os humanos em ação, fosse por uma narrativa dramática ou trágica, ou por uma comédia. A mímesis corresponderia a uma atividade do imaginário sobre o real, que, além de proporcionar prazer, também produz saber. Como afirmou Aristóteles, "é mister ater-se sempre à verossimilhança, de modo que o personagem, em suas palavras e ações, esteja em conformidade com o necessário e verossímil" (apud Ricoeur, 1994). Com isso, o filósofo grego acreditava que a obra poética não era uma simples cópia da aparência, mas uma criação sobre a vida real.

Esta criação se realiza a partir de procedimentos que relacionam a realidade e a ficção. Para Aristóteles, a comédia e a tragédia eram artes a imitar as ações humanas e o faziam pela linguagem, pelas ações boas ou ruins e a construção narrativa (se drama ou comédia). Esta liberdade criativa trabalha com os limites da verossimilhança, ou seja, a obra ficcional tem de se basear em características e personagens do mundo real que sejam verossímeis, críveis. 
O personagem, de acordo com o papel que desempenha no enredo, pode ser protagonista, antagonista ou um personagem secundário, figurante (Gancho, 1991: 14-16). Quanto às descrições física e psicológica, os personagens podem ser planos ou redondos. Os primeiros são aqueles "[...] caracterizados com um número pequeno de atributos, que os identifica facilmente perante o leitor; de um modo geral são personagens pouco complexos" (Gancho, 1991:16). Os mesmos podem ser caricaturas ou tipos. Já os personagens redondos são aqueles mais complexos, dispondo de uma variedade maior de características: podem ser físicas, psicológicas, sociais, ideológicas ou morais, de acordo com a autora. Personagem, no campo da literatura, é o ser ficcional responsável pelo desenrolar do enredo. É considerado uma invenção, uma construção literária, ou um 'ser de papel'. Entretanto, negar a relação entre personagem e pessoa real seria absurdo: os personagens representam pessoas, como acontece nas narrativas jornalísticas. Nestas, seres humanos reais se envolvem em acontecimentos que mudam a rotina de vida, são transformadores em maior ou menor grau e criam novos significados para as ações sociais. Estas transformações operam tanto nas narrativas ficcionais ou nas fáticas pela linguagem, que é um processo de representação do real.

\section{A representação}

A tragédia só imita a realidade porque a recria através de um mythos, de uma fábula, que atinge sua mais profunda essência. (Ricoeur, 1994).

Como processo, a representação é um trabalho ativo, que implica selecionar signos, códigos, fazê-los interagir, e é a partir desta prática que atribuímos valores e significados às nossas práticas sociais. Como lembra Montoro, a representação é uma prática concreta de 
significação. "O trabalho de uma prática representacional consiste em tentar fixar os significados, na tentativa de privilegiar um ponto de vista" (Montoro, 2006: 22).

Mas se a representação tende a fixar significados, estes sofrem um processo de negociação na medida em que o texto interage com a experiência cultural e pessoal do leitor. Foi Barthes quem primeiro estabeleceu um modelo sistemático pelo qual se poderia analisar este processo de negociação de significados. Para ele, existem duas ordens de significação. A primeira é a denotação e descreve a relação entre significante e significado no interior do signo e do signo com o seu referente na realidade externa. A denotação é o sentido primeiro e mais óbvio de um texto, seja ele escrito, falado ou imagético, em filme ou fotografia.

A segunda ordem de significação é a conotação. Segundo Barthes (1971), ela descreve a interação que ocorre quando o signo encontra os sentimentos e emoções dos usuários, assim como os valores da sua cultura. Barthes afirma que numa fotografia a diferença entre conotação e denotação é clara. A denotação é a reprodução mecânica no filme de um objeto para o qual a câmera aponta. Já a conotação é a parte humana do processo; é a seleção do que incluir no enquadramento, que foco, que ângulo de câmera, que tipo de filme usar, se colorido ou preto e branco. Denotação é o que é fotografado. Conotação é como é fotografado.

Outro conceito que, segundo Barthes, explica como o signo trabalha é o de mito. Um mito é uma estória ou narrativa pela qual uma cultura explica ou compreende algum aspecto da realidade ou da natureza. Os mitos primitivos falavam de vida e morte, homens e deuses, o bem e o mal. Já os mitos modernos tentam explicar a masculinidade e a feminilidade, a família, a ciência. Barthes pensa no mito como uma cadeia de conceitos relacionados. Se a conotação é a segunda ordem de significante, o mito é a segunda ordem do significado. O mito é o significado cultural que é ativado pelo signo, mas que pré-existe ao 
signo. Atualmente, um mito frequente nos relatos fílmicos é a construção do personagem como uma epopeia de herói. Um mito que está presente também em algumas narrativas jornalísticas.

O herói e sua jornada vêm a ser o que o antropólogo Joseph Campbell chamou de monomito, um conceito que explica como o personagem percorre um ciclo completo para cumprir uma missão ou tarefa. Como conceito de Narratologia, o termo apareceu pela primeira vez em 1949, no livro de Campbell O Herói de Mil Faces. Campbell descreve as narrativas de Gautama Buddha, Moisés e Cristo em termos de monomito e afirma que mitos clássicos de muitas culturas seguem um padrão básico. Campbell define este padrão narrativo como a Jornada do Herói (2007), cujos estágios são:

Mundo Comum - o mundo normal do herói antes da história começar;

- O Chamado da Aventura - um problema se apresenta ao herói: um desafio ou a aventura;

- Reticência do Herói ou Recusa do Chamado - o herói recusa ou demora a aceitar o desafio ou aventura, geralmente porque tem medo;

- Encontro com o mentor ou Ajuda Sobrenatural;

- Cruzamento do Primeiro Portal - o herói abandona o mundo comum para entrar no mundo especial ou mágico;

- Provações, aliados e inimigos;

- Aproximação - o herói tem êxitos durante as provações;

- Provação difícil ou traumática - a maior crise da aventura, de vida ou morte;

- Recompensa - o herói enfrentou a morte, se sobrepõe ao seu medo e agora ganha uma recompensa;

- O Caminho de Volta - o herói deve voltar para o mundo comum.

A força dramática de um enredo está na busca de realização de um desejo do personagem, herói ou não, e na oposição das forças 
de antagonismo que dificultam ou impedem que ele alcance aquilo que quer. Na análise, o ponto de partida é caracterizar o protagonista da história, considerando as relações que mantém com outros personagens. Todos têm a função, no enredo, de criar fios narrativos que movimentam a intriga. O protagonista é o personagem mais bem desenvolvido na história. Ele é o centro nervoso da trama que sustenta o eixo narrativo. Todos os eventos, personagens e elementos da história giram ao seu redor. Já o antagonista é o personagem (que pode também ser um objeto, animal, monstro, espírito, instituição, grupo social, limitação de ordem física, psicológica, social ou cultural) que traz ou representa uma ameaça, obstáculo, dificuldade ou impedimento ao que o protagonista deseja conquistar. Muitas vezes, o protagonista pode ser levado pelos acontecimentos, como se estes fossem a mão do destino.

\section{$O$ acontecimento e a narrativa}

O acontecimento é da ordem do inesperado, do novo ou do inédito, e introduz uma descontinuidade, reportando-se à noção fenomenológica do presente, como "o hoje em função do qual há um amanhã e um ontem” (Ricoeur, 2014: 158)

Como lembra a pesquisadora Vera Veiga França, da UFMG, o acontecimento é um conceito que tem presença importante nos campos da história e da filosofia, mas só recentemente ele vem ocupando espaço nos estudos de Comunicação, especialmente na Teoria do Jornalismo, em que aparece como sinônimo do fato ou para distinguir a noticiabilidade de ocorrências do cotidiano. Uma linha mais recente de pesquisa vem abordando o acontecimento como uma transformação que ocorre no domínio da experiência humana e que tem a capacidade de interferir no quadro da normalidade. 
É "a ocorrência desencadeadora de sentidos" (Quéré, 2012) cuja complexidade extrapola a narrativa factual ou jornalística.

Ao desorganizar o presente, o acontecimento instala uma temporalidade estendida, convoca um passado com o qual possa estabelecer ligações, anuncia futuros possíveis... Ele nos serve para perceber a ruptura, o alcance, a potencialidade, enfim, abertos por certos fatos. (França, 2012: 48).

O Jornalismo vive no ritmo dos acontecimentos, que nos permitem ler o mundo a partir dos fatos e dos sentidos que eles desencadeiam. Como Adriano Rodrigues costuma afirmar, "é acontecimento tudo aquilo que irrompe na superfície lisa da história dentre uma diversidade aleatória de fatos virtuais" (Rodrigues, 1993: 27). Os acontecimentos vão sendo construídos pela linguagem, pela narrativa factual e também pela narrativa ficcional, que nos fornecem uma dimensão simbólica, de significação nova sobre o real. "Produzem a compreensão de um estado de coisas reconstituídas em tramas e narrativas, nas quais aparecem os atores que desempenham papéis" (Quéré, 2012: 68).

É importante a distinção que Sodré faz entre fato e acontecimento (Sodré, 2009: 33). Enquanto o acontecimento se pauta pela atualidade, o fato, mesmo inscrito na história, é uma elaboração intelectual. Por sua vez, Mouillaud afirma que "o acontecimento é a sombra projetada de um conceito construído pelo sistema da informação, o conceito do fato" (Mouillaud, 2012: 51). Assim, a informação jornalística parte de objetos tidos primeiro como factuais para obter, por intermédio do acontecimento, alguma clareza sobre o fato social e histórico. "É, portanto, uma atividade que transcende a mera distribuição de relatos sobre a realidade. Visto como uma narrativa, o relato jornalístico envolve enredos, conflitos e personagens para se desenvolver" (Mota, 2012: 16). 
Para uma maior compreensão desta concepção, um bom exemplo de meta-acontecimento é o "11 de setembro". Para além das imagens televisivas que noticiaram a ocorrência, é o próprio discurso do fato que emerge como notável. Os eventos desencadearam enormes dimensões sociais e políticas que ainda não se esgotaram. $\mathrm{O}$ "11 de setembro" se tornou tema de memória coletiva, a ser relembrado a cada ano, transformado em efeméride pela grande mídia, o que contribui para atualizar e desdobrar os sentidos, conferindo uma maior compreensão do ocorrido.

A concepção de acontecimento para além da narrativa jornalística e mesmo da narrativa ficcional permite perceber sua abrangência como transformação da vida de muitas pessoas envolvidas, das mortes ocorridas, e do seu poder de continuar provocando sentidos novos em outras ocorrências. Outro exemplo claro do conceito foi a catástrofe conhecida como tsunami, que atingiu o sudeste da Ásia em 2004, e que ficou para sempre na memória coletiva não só dos povos asiáticos, mas de toda a humanidade. O acontecimento tem, nesta perspetiva, um antes e um depois do fato que se tornou conhecido pelas narrativas midiáticas. Ele será lembrado por muitos anos não só pelos que viveram a tragédia daqueles dias, mas por todos os que possam temer sua repetição.

É, portanto, pela vivência de acontecimentos grandes ou triviais que se estabelecem as interações sociais, expondo identidades e deslocando os participantes do fato para as funções de protagonistas ou antagonistas nas narrativas que se seguirão. $\mathrm{O}$ acontecimento tem relação direta com os personagens envolvidos numa experiência. Como destaca Quéré, "o verdadeiro acontecimento não é unicamente da ordem do que ocorre, do que se passa e se produz, mas também do que acontece a alguém" (Quéré, 2005: 61). Ou seja, o acontecimento é um fenômeno que afeta e transforma aqueles que o vivem. É o que resulta da própria transformação dos sujeitos. E, em consequência, da própria transformação da comunidade a que pertence o indivíduo, 
permitindo que novos significados sejam partilhados. É pelo acontecimento que a narrativa instala os conflitos entre os personagens.

\title{
Narrativas e significações
}

\author{
Narrar é uma forma de dar sentido à vida. Na verdade, as \\ narrativas são mais que representações: são estruturas que \\ preenchem de sentido a experiência e instituem significação \\ à vida humana. Narrando, construímos nosso passado, nosso \\ presente e nosso futuro. (Motta, 2013: 18).
}

Duas narrativas fazem parte do material empírico selecionado para a análise da construção de significados a partir dos personagens e dos acontecimentos em que se envolvem. A primeira narrativa é ficcional e trata de um personagem que foi concebido nos primeiros anos do século $\mathrm{XX}$, quando começa a se forjar a ideologia de um Brasil fruto de uma mestiçagem de três raças. Macunaíma, de Mário de Andrade, é o personagem ficcional onde vamos procurar compreender os traços de brasilidade pela análise da narrativa. O segundo texto a ser analisado nos apresenta um personagem de um relato jornalístico, baseado num ser real, também fruto da selva, o trabalhador do canavial. A reportagem analisada é "O canavial esmaga o homem", da antiga revista Realidade. Qual dos dois se assemelha mais ao personagem de que fala Campbell, ao descrever as jornadas de busca e realização que consagram os heróis?

A análise crítica da narrativa supõe três planos: plano da expressão, plano da história ou estória e plano da meta-narrativa. O plano da expressão é o plano da linguagem, o da superfície do texto, por meio do qual o enunciado é construído pelo narrador. Tanto para o texto ficcional como para o factual, a análise textual permite examinar figuras de linguagem, caminhos de representação de personagens 
e de suas ações, e recursos narrativos que ajudam a perceber a intencionalidade do narrador e suas estratégias persuasivas. É neste plano também que se identificam os protagonistas e antagonistas, as situações de conflito e as intrigas que permitem a evolução das ações. Nesta análise privilegiamos as representações dos personagens, de que forma são descritos e apresentados pelo texto.

O plano da estória, ou da história como preferem alguns, é o plano da significação ou do conteúdo propriamente dito. Neste plano, a mimese, como a define Ricoeur (1994), permite representar acontecimentos e fatos da vida do personagem, situações em que ele se envolve, numa operação textual de imitação criativa da vida real no caso de narrativa fática, ou da vida imaginada, no caso da narrativa ficcional. Estes acontecimentos revelam os significados que os personagens constroem sobre si mesmos, a partir da atividade criativa do narrador.

O terceiro plano da meta-narrativa, conforme acentua Motta, é o plano da estrutura profunda, que evoca imaginários culturais. É o conflito que tece a trama através do relato de incidentes, rupturas, descontinuidades. A meta-narrativa é quase sempre não dita, mas contradita. É uma verdade ou um imaginário que se constrói em torno de um tema e que volta à memória sempre que o tema se torna objeto de algum relato, especialmente jornalístico. A meta-narrativa se vale de acontecimentos anteriores, que provocaram significados diferentes, de fundo cultural, para retomar estes sentidos em novo texto. A análise da meta-narrativa é um movimento de sair do texto, do plano da expressão, para buscar os fios narrativos que trazem os sentidos que se fixaram na memória coletiva.

$\mathrm{Na}$ ficção, como no relato jornalístico, a análise da meta-narrativa permite res-significar os novos acontecimentos à luz de fatos anteriores. Para os que seguem o antropólogo Joseph Campbell, o plano da meta-narrativa permite analisar as jornadas de um herói, tendo como pano de fundo as oposições entre o bem e o mal, a vida 
e a morte, diferentes valores culturais presentes em comunidades diversas, além dos mitos em geral.

Nesta análise, os dois personagens serão examinados a partir de uma perspetiva de identidade e a construção de brasilidade de cada um deles, levando em conta os cenários onde os acontecimentos descritos ocorrem, ficcionais ou reais, e o tempo histórico em que suas estórias são narradas.

\section{Macunaíma: herói da brasilidade}

No caminho pelo Araguaia o exército de passarinhos saúda o herói, que volta a assumir o título de Imperador do Mato-Virgem. Um dia um homem passou pelo Uraricoera, agora uma terra desabitada. Uma voz chegou aos seus ouvidos. Tratava-se do aruaí para quem Macunaíma contara sua história. A ave reproduziu toda essa saga para o viajante e depois partiu para Lisboa. O ouvinte era o escritor, Mário de Andrade, que retratou essas aventuras nesse livro. (Epílogo de Macunaíma, 2008).

Com o romance O Guarani, de José de Alencar, a brasilidade se tornou, pela primeira vez, tema da literatura brasileira, quando o movimento romântico construiu um ser nacional fruto da união entre índios e brancos, deixando o negro naquele momento identificado apenas com a força de trabalho e, portanto, sem direito à cidadania. Foi a partir do movimento abolicionista e das transformações sociais e políticas por que passava o Brasil no começo do século XX que o negro seria integrado às preocupações nacionais e se tornaria personagem de uma literatura mais realista. É nesse momento também que surge o mito das três raças, uma epopeia de um Brasil-cadinho que é forjado nas selvas tropicais.

Como nas sociedades primitivas, o mito é cosmológico, no entender de Ortiz (1987: 38) que o considera a origem do moderno Estado 
brasileiro, ponto de partida de uma visão mítica que antecede a própria realidade. A partir das primeiras décadas do século XX, o Brasil passa de uma economia escravagista para outra de tipo capitalista, saindo ainda de uma organização política monárquica para a adoção do sistema republicano. Começa um processo de industrialização e urbanização, novas cidades surgem e uma classe média se desenvolve. O Brasil entra na era moderna. Se o modernismo é considerado por muitos como um ponto de referência, é porque "este movimento cultural trouxe consigo uma consciência histórica que até então se encontrava de maneira esparsa na sociedade" (Ortiz, 1987: 40). É naquele momento que Gilberto Freyre reedita a temática racial para constituí-la em objeto privilegiado de estudo, uma chave para a compreensão do Brasil. Freyre transforma a negatividade do mestiço, afirmada até então, em uma positividade que vai redesenhar os contornos da identidade brasileira. "O que era mestiço torna-se nacional", na expressão usada por Ortiz. Os modernistas do século XX propõem devorar a cultura europeia, numa antropofagia cultural que busca acabar com a importação de práticas artísticas e literárias da velha Europa. "Esta postura vai permitir aos modernistas a busca de expressão da brasilidade, pintando o homem brasileiro das cidades e do sertão, assim como as paisagens proletárias de São Paulo" (Mota, 2014:10).

Um personagem surge então naquele caldo de cultura. Aproximando o folclore, os rituais populares e as lendas indígenas, Mário de Andrade, paulista, culto e viajado, concebe Macunaíma, um ser da floresta primitiva e que vai morar na cidade grande, experimentando a contradição que significava viver no Brasil em 1930. No texto, etnia e cultura aparecem como sinônimos e, às vezes, como antônimos. Em Macunaíma, Mário de Andrade proclama a síntese nacional, isto é, a presença frente a frente das três etnias que formam o povo brasileiro. Macunaíma surge, assim, como um personagem que vai ser objeto de uma inclusão cultural precoce para a época, um retrato do brasileiro que mistura qualidades e defeitos e experimenta de tudo um pouco. 
Em 17 capítulos, o livro apresenta a saga de um brasileiro que descobre o Brasil, suas crenças e ideias, numa aventura mista de jornada de herói, como a define Campbell. Macunaíma nasce e já manifesta sua principal característica: a preguiça. O herói vive às margens do mítico rio Uraricoera com sua mãe e seus irmãos, Maanape e Jiguê, numa tribo amazônica. Após a morte da mãe, os três irmãos partem em busca de aventuras. Macunaíma encontra Ci, Mãe do Mato, rainha das Icamiabas. Depois de dominá-la, com a ajuda dos irmãos, faz dela sua mulher, tornando-se assim imperador do Mato Virgem.

O herói tem um filho com Ci e esse morre, ela morre também e é transformada em estrela. Antes de morrer dá a Macunaíma um amuleto, a muiraquitã (pedra verde em forma de sáurio), que ele perde e que vai parar nas mãos do mascate peruano Venceslau Pietro Pietra, o gigante Piaimã, comedor de gente. Como o gigante mora em São Paulo, Macunaíma e seus irmãos vão para lá, na tentativa de recuperar a muiraquitã. Após falhar com o plano de se vestir de francesa para seduzir o gigante e recuperar a pedra, Macunaíma foge para o Rio de Janeiro. Lá encontra Vei, a deusa sol, e promete casamento a uma de suas filhas, mas namora uma portuguesa e enfurece a deusa. Depois de muitas aventuras por todo o Brasil, na tentativa de reaver a sua pedra, o herói a resgata e regressa para a sua tribo. Ao fim da narrativa, vem a vingança de Vei: ela manda um forte calor, que estimula a sensualidade do herói e o lança nos braços de uma uiara traiçoeira, que o mutila e faz com que ele perca de novo - dessa vez irremediavelmente - a muiraquitã. Cansado de tudo, Macunaíma vai para o céu transformado na Constelação da Ursa Maior.

Como o próprio Mário declarou, ele teve muitas intenções ao escrever Macunaíma, tratando de diversos problemas brasileiros: a falta de definição de um caráter nacional, a cultura submissa e dividida do Brasil, o descaso para com as nossas tradições, a importação de modelos socioculturais e econômicos, a partir de uma visão antropofágica em moda na década de 1930. Uma preocupação de 
Mário de Andrade parece evidente: buscar uma identidade cultural brasileira. Esta cultura nacional seria formada pelas diversas culturas populares existentes. Na visão de Mário de Andrade, o Brasil englobaria numa só as representações culturais das regiões do país. Por isso Macunaima vive lendas, folclores, costumes, falares diversos e mistura crenças religiosas, como explica o escritor:

Um dos meus interesses foi desrespeitar lendariamente a geografia e a fauna e flora geográficas. Assim desregionalizava o mais possível a criação ao mesmo tempo que conseguia o mérito de conceber literariamente o Brasil como entidade homogênea - um conceito étnico nacional e geográfico (Andrade, 2008).

A narrativa é construída na terceira pessoa pelo narrador, o próprio escritor. A história se passa no século $\mathrm{XX}$, mas o tempo mítico predomina, pois, os mitos e lendas não se enquadram na cronologia tradicional. Este espaço mítico é reforçado pelas mudanças de cenário da narrativa, que transporta Macunaíma para várias regiões do país num piscar de olhos. Da selva amazônica sai para São Paulo, onde descobre as máquinas. As palavras iniciais da trama já tentam construir um perfil sociológico do personagem: 'Macunaíma nasceu negro e feio. Foi parido pela índia Tapanhumas no rio Uraricoera. Ele permaneceu seis anos sem falar, por pura preguiça. Se o incitavam a falar exclamava: - Ai! Que preguiça!... e não dizia mais nada'. Ao completar seis anos, o herói ganhou água em um chocalho e a partir daí passou a falar sem problemas. Foi para a mata e virou príncipe. Na maioridade, Macunaíma teve uma ideia. Ele iludiu sua mãe, pediu que ela cerrasse os olhos e, quando ela os abriu de novo, os dois estavam na outra margem do rio, rodeados de alimentos fartos. Mas a índia quis levar uma parte da refeição para os outros filhos. O protagonista ficou com raiva e os transportou mais uma vez para a velha casa. Voltaram a sentir fome. 
No capítulo dois, o autor oferece uma primeira representação de Macunaíma como brasileiro. O texto fala que a avó do menino pegou uma gamela cheia de caldo envenenado de aipim e jogou a lavagem no piá. Macunaíma se afastou, mas só conseguiu livrar a cabeça, todo o resto do corpo se molhou. "Porém a cabeça não molhada ficou prá sempre rombuda e com carinha enjoativa de piá". Para o escritor, o episódio caracteriza o personagem como uma representação do país, um gigante que ainda pensa como criança. Da Mãe do Mato, Macunaíma ganha um muiraquitã, uma pedra verde. É seu talismã que perde e vai procurar em São Paulo. Antes da viagem, a primeira metamorfose: ele toma banho em uma água mágica e sua pele fica branca, os olhos azuis e os cabelos loiros. Seu irmão tenta se banhar na mesma água, mas só consegue um tom de bronze para a pele. Mais uma representação simbólica da mistura de etnias do brasileiro que produz uma grande variedade de cores de pele.

Em São Paulo, o herói encontra seu antagonista, o gigante Piaimã, encarnação do mercador peruano Pietro Pietra, que havia roubado seu muiraquitã. Piaimã come as pessoas e vive com a Caapora, mais uma lenda incorporada à narrativa. Para se livrar do gigante, Macunaíma vai para o Rio de Janeiro, onde frequenta a macumba da Tia Ciata. Nos capítulos seguintes, Macunaíma inventa histórias de caçadas fartas ao se frustrar em uma tentativa de apanhar uma caça melhor no Bosque da Saúde. Todos descobrem a mentira, confessada por ele mesmo. Então ele vai pescar no Tietê e cai na rede de Ceiuci, esposa de Piaimã. Ele é deixado na sala da casa do gigante enquanto a mulher vai preparar tudo para assá-lo. Mas a filha caçula de Ceiuci o encontra e o esconde no quarto dela, onde os dois começam a brincar. No fim da história ele teve de fugir da mãe. Nessa fuga passa por inúmeras aventuras e por boa parte do país. No fim o tuiuiú virou avião e o trouxe de volta para São Paulo. A filha caçula do gigante se transforma em cometa. 
Tanto no plano da expressão como no plano da estória, o livro envolve o personagem no universo mítico do Brasil, usando não só nomes indígenas como cenas de caçadas no mato e alimentos típicos de várias regiões. No plano da meta-narrativa, a representação de Macunaíma tem sido interpretada como símbolo do homem brasileiro, que teria sua natureza psicológico-cultural identificada no subtítulo dado ao livro: 'sem nenhum caráter'. Para alguns autores, a expressão significaria apenas 'sem características próprias', sem identidade definida, como, ao que parece, era a ideia de Mário de Andrade. Se de um lado há uma imagem de 'mau-caráter', pelas travessuras e brigas em que Macunaíma se mete, por outro há uma leitura do personagem como 'matreiro, esperto, um brasileiro que sempre tem seu jeitinho'. Um malandro ou um herói?

Como define Da Matta, o malandro é aquele que escolhe ficar no meio do caminho juntando, de modo quase sempre humano, a lei impessoal e a amizade e a relação pessoal. Esta malandragem parece caracterizar o personagem Macunaíma, que é capaz de proezas incríveis e aventuras míticas, mulherengo e preguiçoso, mas que vence o gigante adversário ao final e recupera sua pedra mágica, a muiraquitã. Viajante da floresta para a cidade grande, dando um jeito de sobreviver em ambas, Macunaíma não tem apenas o gosto da trapaça, mas revela um jeito de ser e de sobreviver que caracteriza o brasileiro, que vive num sistema em que a casa nem sempre fala com a rua e as leis formais da vida pública nada têm a ver com as boas regras da moralidade costumeira. "Num mundo tão profundamente dividido, a malandragem e o 'jeitinho' promovem uma esperança de tudo juntar numa totalidade harmoniosa e concreta. Antes de ser um acidente ou mero aspecto da vida social brasileira, coisa sem consequência, a malandragem é um modo possível de ser" (Da Matta, 1986: 105). 


\section{O herói invisível}

Farofa, taquinho de carne há 54 anos. É só. Asneira dizer que come. A gente enche a barriga, mas a danada da fome volta logo. Sou cabra bom. Não tenho vexame de dizer (Gregório, in: Realidade, 1970).

Nem jeitinho, nem ritual mágico e nem a ajuda da Mãe do Mato foram capazes de encher de comida o prato de Gregório. Não há milagres na história de um personagem real, um brasileiro como tantos outros, lutando para sobreviver em condições precárias. Com 54 anos e apenas três dentes, Gregório é o personagem principal da reportagem "O canavial esmaga o homem”, tema da edição 46 da revista Realidade, em janeiro de 1970. A reportagem faz parte de uma série de artigos da revista, publicada entre 1969 e 1973, que retratou os brasileiros de diferentes rincões do Brasil. Estes brasileiros foram os personagens reais, embora invisíveis, de narrativas construídas durante os anos de milagre econômico da ditadura militar.

Utilizando técnicas literárias, os repórteres Jorge Andrade e Jean Solari são os narradores de um texto que destaca a pobreza, a dificuldade para obter alimentos, a incerteza sobre o futuro, recriando a realidade de um Brasil pouco conhecido naquele momento histórico e que, para muitos, continua invisível até hoje. Eles viajaram para o estado do Pernambuco em busca dos engenhos de rapadura, dos canaviais e dos homens que são os responsáveis por manterem o canavial em atividade: o trabalhador do engenho. O canavial é apresentado ao leitor como um personagem vivo, que vai tomando os espaços naturais, crescendo muito rapidamente e modificando a paisagem. A cana também é dotada de armas naturais, que maltratam os trabalhadores de engenho: as folhas são como navalhas.

No plano de expressão da narrativa o canavial é representado como um mar verde que aprisiona homens, mulheres, crianças e 
idosos. Quem olha a partir de um prisma externo, enxerga apenas as folhas que se mexem com o vento. Quem está ali dentro vê a sua própria história ligada ao canavial. Podemos observar isso quando o narrador nos apresenta o personagem principal desta narrativa, Gregório. Assim mesmo, sem sobrenome. Um homem humilde, analfabeto, envelhecido, que se levanta todos os dias às três horas da madrugada, pega suas armas e vai para o canavial. É lá que busca o sustento, a paga que permitirá o acesso ao alimento.

O canavial passa a ser descrito como o antagonista, devido aos riscos que significa para os trabalhadores. Ele representa o perigo que o herói vai ter de enfrentar na luta diária. Além da própria cana, que solta pelos que entram na pele como espinhos, também existem perigos naturais, como é o caso das cobras escondidas nas touceiras de cana. Se os espinhos são a representação de um obstáculo conhecido, as cobras são o perigo desconhecido, porque o homem não tem como prever onde elas estão ou quando o atacarão.

A construção do ambiente pela narrativa inclui os elementos naturais da região e até os sons que inundam o local. Após relatar que a cana expulsou todos os animais, ocupou espaços que antes eram tomados por outra vegetação e incluiu os ambientes de convívio do homem, uma frase descreve o cenário da região: ali "há um mar verde que, quando ondula batido pelo vento, produz um som seco e áspero" (Andrade, 1970: 34). Após a apresentação do espaço físico, tomado pelo canavial, a narrativa se dedica ao personagem, Gregório, descrito como um ser humano que gosta de sonhar.

A narrativa introduz Gregório durante a madrugada, com ele ainda deitado. O narrador mescla as informações referentes ao canavial com dados que traçam as características físicas e sociais daquele espaço. "Na noite que custava a passar, Gregório olhou à sua volta, medindo as paredes do quarto: 3 por 2 metros" (Andrade, 1970: 34). Neste quarto dormem Gregório, sua mulher Dalvanise, Matilde e Madalena, filhas pequenas. Na sala ainda dormem Severino e Joaquim, também 
filhos. Gregório teve sete filhos, dos quais cinco ainda moram com ele. Quanto às crianças, o mais velho daqueles já foi convocado a trabalhar como adulto no canavial:

\begin{abstract}
Severino, de oito anos, não ia ao corte de cana naquele dia: estava com o peito cheio. Cabrinha macho, esse! Com a ajuda dele, tinha cortado tonelada e meia de cana por dia durante a semana. Gregório sentiu frio e encolheu o corpo: acha que é falta de sangue. É por isso que o corpo não se esquenta (Andrade, 1970: 34).
\end{abstract}

Ao sair para trabalhar, Gregório pensa na semana seguinte, quando será lua cheia. Durante estes períodos, quando a noite é bem iluminada, os homens trabalham por mais tempo, recebem mais dinheiro. A narrativa introduz o imaginário do personagem, informando que é pensando em um presente para Dalvanise que ele dá início a sua caminhada de oito quilômetros até o local do corte da cana. Caminhando, ele reflete sobre a influência do canavial sobre a vida de todos, até dos que ali não residem. O texto busca elementos que equiparem o trabalhador à cana. Após um dia de trabalho, ambos tornam-se bagaço, restos. O dono do engenho é representado apenas pelo seu carro. Assim como as máquinas do engenho, a 'máquina' do dono causa emoções positivas ao trabalhador. Ao ver o carro, o texto reforça o imaginário do personagem, que se lembra do pagamento no dia seguinte. Na jornada do herói é um dia especial, porque é sempre seguido por uma visita ao bar para aliviar a tensão do dia a dia e esquecer as dificuldades da vida.

Não são homens, mulheres e crianças vivendo onde gostariam. Estão ali porque não têm outra condição de trabalho. A alimentação não corresponde ao esforço que despendem: a farofa e o 'taquinho' de bacalhau mal dão para se manterem 
de pé. Aguentam-se porque comem a própria cana, que é rica em glicose e sacarose (Andrade, 1970: 37).

A narrativa jornalística usa recursos metafóricos, falando em luta, combate, para dramatizar a vida das pessoas, que estão presas a um destino no qual o caminho é sempre o mesmo: ir para o canavial durante a madrugada e voltar de lá no final da tarde. O canavial é queimado com o intuito de tornar o corte da cana menos perigoso. Em meio a todas as dificuldades do ambiente e do contexto, o que sufoca e faz o homem chorar é a fumaça. Por ser forte e corajoso, não admite para si mesmo reclamar daquele estilo de vida. Mas o corpo fala mais alto, no momento em que o força a chorar em meio à fumaça. É a forma que o sofrimento usa para se expressar. O corpo reclama, expressa os sentimentos do homem, que não consegue verbalizá-los por medo de mostrar fraqueza. Com toda a dificuldade, o personagem cumpre a sua jornada e chega ao alto do morro, vence a batalha diária, derrota o canavial, consegue seu objetivo inicial. Apesar de ganhar aquela batalha, o homem arqueja, está 'morto', porém de cansaço. Ambos estão mortos, o homem e a cana, cada um a sua maneira. E o herói volta a casa para recomeçar tudo outra vez no dia seguinte.

A partir da estrutura do texto, seguindo o personagem ao longo de um dia de trabalho, os repórteres levam para perto do leitor a imagem do trabalhador do engenho. A humanização do personagem permite que o leitor se identifique com ele, compreenda suas aflições e compartilhe o cenário no qual acontecem as cenas da luta. A reportagem da revista Realidade apresenta sem retoques a dura vida dos trabalhadores do canavial, esmagados por problemas como falta de educação, de saúde, explorados como mão de obra barata, vivendo no limite da sobrevivência. São personagens invisíveis recuperados pela revista Realidade para relatar como viviam milhões de brasileiros naquele momento histórico em que o milagre econômico mostrava um país em desenvolvimento que não incluía todos os seus cidadãos. 
A perspetiva adotada aqui é a de encarar o trabalho da revista Realidade, como da mídia jornalística em geral, como uma prática de memória, conforme propõe Babo-Lança (2012) que estuda as relações entre o acontecimento narrado na mídia e a memória coletiva. No caso da reportagem da revista Realidade aqui analisada, temos um exercício de memória a partir do acontecimento jornalístico que, embora narrado em 1970, se constituiu como um documento histórico, e, por isso, detém um duplo valor, de inscrição e de narrativa que reconstrói o passado. Ao reavivar a memória, o texto reapresenta os significados construídos nos idos de 1970 e permite reavaliar sua importância para o presente e para a busca da compreensão do personagem em estudo, o brasileiro, incorporando-o a uma meta-narrativa cultural que tem raízes profundas.

\section{Considerações finais}

Ao colocar em confronto duas narrativas, a ficcional, apresentando Macunaíma como uma síntese do caráter do brasileiro, e a jornalística, mostrando a dura realidade de um trabalhador de engenho, esta análise procurou contribuir para a percepção da ambiguidade que caracteriza o significado de ser brasileiro. Esta dicotomia tem base em dois princípios que se opõem desde os tempos coloniais. A reflexão é de Sérgio Buarque de Holanda no livro Raízes do Brasil, quando examina no segundo capítulo a diferença entre o trabalho e a aventura. Holanda (1988) assinala que esses dois princípios regularam diversamente as atividades dos portugueses que participaram da grande aventura de posse das terras brasileiras no período colonial.

Para o aventureiro, o ideal é colher o fruto sem plantar a árvore. Vive dos espaços ilimitados, dos projetos vastos, dos horizontes distantes. O trabalhador, ao contrário, é aquele 
que enxerga primeiro a dificuldade a vencer, não o triunfo a alcançar. (Holanda, 1988:13).

Segundo o autor, o que o português vinha buscar nas terras do novo mundo era, sem dúvida, a riqueza, mas riqueza que custa ousadia, não riqueza que custa trabalho. O princípio que, desde os tempos mais remotos da colonização, norteou a criação da riqueza no país valia especialmente para a produção agrária "onde todos queriam extrair do solo excessivos benefícios, sem grandes sacrifícios". E o autor destaca: "não foi a rigor uma civilização agrícola o que os portugueses instauraram no Brasil; foi, sem dúvida, uma civilização de raízes rurais" (Holanda, 1988: 21).

No entanto, se o gosto pela aventura levou os portugueses a se embrenharem cada vez mais em regiões distantes, alargando a posse sobre as terras antes fixadas pelo Tratado de Tordesilhas, sem dúvida foi a necessidade de trabalhar e fazer a terra render seus frutos que permitiu a fixação agrária. O personagem Gregório, da reportagem da revista Realidade, é com certeza um retrato dos portugueses que para o Brasil vieram como colonos, para trabalhar na lavoura da cana de açúcar. Ele descende dos portugueses, dos índios e também dos africanos que, juntos, enfrentaram a dura tarefa de trabalhar nos engenhos. A matriz cultural está presente nesses heróis invisíveis, que têm a cultura e a ética do trabalho, a fixação na terra apesar das dificuldades e da miséria reinante. São heróis que também sonham, mas permanecem presos ao seu canavial, que lhes dá magro sustento. Vivem alheios às inovações tecnológicas e usam a mesma foice para cortar a cana que foi usada pelos seus ancestrais.

Como exemplo da outra matriz cultural portuguesa, a da aventura, temos a narrativa de Macunaíma, o herói que sai para o mundo em busca de uma pedra mágica, que busca a realização fácil, que apela para o jeitinho sempre que se vê em dificuldades. Muitas vezes desperta tarde demais dos seus sonhos. Para Da Matta, o jeitinho pode 
ser um atalho para realizar mais rápido um desejo. "Que modo é este?" pergunta Da Matta. E ele mesmo responde: "é, sobretudo, um modo simpático, desesperado ou humano de relacionar o impessoal com o pessoal. É um modo pacífico e até mesmo legítimo de resolver problemas". (Da Matta, 1986: 99).

Vivendo a realidade da luta pela sobrevivência diária, reproduzida pela reportagem de Realidade, sonhando com a possibilidade de aventuras em terras brasileiras como as vividas por Macunaíma, o brasileiro hoje é o protagonista de uma construção identitária que ainda se divide entre o real e o sonho. Mas, cada vez mais, a realidade se impõe e o brasileiro vai descobrindo que não existe mágica, nem Muiraquitã, nem mãe do Mato capaz de transformar as condições de vida do país, da noite para o dia. É um processo que desmistifica as narrativas lendárias e leva o personagem a enfrentar a vida com o trabalho duro que marcou a história do país em quinhentos anos.

\section{REFERÊNCIAS BIBLIOGRÁFICAS}

ANDRADE, J. (1970). O canavial esmaga o homem. São Paulo: Realidade.

ANDRADE, M. (2008). Macunaíma. Rio de Janeiro: Nova Fronteira.

BABO-LANÇA, I. (2012). "Acontecimento e Memória". In FRANÇA, V. V. e OLIVEIRA, L. Acontecimento: reverberações. Belo Horizonte: Autêntica.

BARTHES, R. (1971). Análise Estrutural da Narrativa. Petrópolis, R/J: Editora Vozes. BUARQUE DE HOLANDA, S. (1988). Raízes do Brasil. Rio de Janeiro: José Olympio Editora.

CAMPBell, J. (2007). O herói de mil faces. São Paulo: Editora Pensamento.

DAMATTA, R. (1986). O que faz o brasil Brasil? Rio de Janeiro: Rocco.

FRANÇA, V. V. (2012). "O acontecimento para além do acontecimento: uma ferramenta heurística". In FRANÇA, V. V. E OLIVEIRA, L. (Orgs.). Acontecimento: Reverberações. Belo Horizonte: Autêntica.

GANCHO, C. V. (1991). Como Analisar Narrativas. São Paulo: Editora Ática. 
MONTORO, T. e CALDAS, R. (Orgs.) (2006). De olbo na imagem. Brasília: Fundação Astrojildo Pereira e Editorial Abaré.

MOTA, C. M. (Org.) (2012). Narrativas Midiáticas. Florianópolis: Insular.

MOTA, C. M. e ALMEIDA, P. (2014). "Jornalismo e redes sociais: identidade e cidadania”, in Revista eletrônica Eco-Pós. Rio de Janeiro: Editora da Universidade Federal do Rio de Janeiro.

MOTTA, L. G. (2005). Narratologia: teoria e análise da narrativa jornalística. Brasília: Casa das Musas.

MOTTA, L. G. (2013). Análise Crítica da Narrativa. Brasília: Editora Universidade de Brasília.

MOUillaud, M.; PORTO, S. (Org.) (2012). O jornal: da forma ao sentido. $3^{\mathrm{a}}$. ed. Brasília: Editora Universidade de Brasília.

ORTIZ, R. (1987). Cultura brasileira e identidade nacional. 3. ${ }^{a}$ Ed., São Paulo: Editora Brasiliense.

PROPP, V.; MELETINSKII, E. M. (1970). Morphologie du conte: suivi de Les transformations des contes merveilleux et de L'estude structurale et typologique du conte. Paris: Seuil.

QUÉRÉ, L. (2005). "Entre facto e sentido: a dualidade do acontecimento", in Trajectos: revista de Comunicação, Cultura e Educação. Lisboa, n.6, pp.59-76.

QUÉRÉ, L. (2012). "A dupla vida do acontecimento: por um realismo pragmatista”, in FRANÇA, V. V. E OLIVEIRA, L. (Orgs.). Acontecimento: Reverberações. Belo Horizonte: Autêntica.

RICOEUR, P. (1994). Tempo e Narrativa. Campinas: Editora Papirus.

RICOEUR, P. (2014). A Memória, a história, o esquecimento. Campinas: Editora Unicamp.

RODRIGUES, A. D. (1993). "O Acontecimento", in TRAQUINA, N. (Org.) Jornalismo: questões, teorias e "estórias". Lisboa: Vega.

SODRÉ, M. (2009). A narração do fato. Petrópolis: Editora Vozes. 